\title{
Consumer perceptions on satisfaction and word of mouth in smallholder horticultural stores in an emerging economy
}

\author{
Lerato Seopela $^{\mathrm{a}}$ and Valencia Melissa Zulu ${ }^{\mathbf{a}^{*}}$
}

\begin{abstract}
${ }^{a}$ School of Business Sciences, Marketing Department, University of the Witwatersrand, Johannesburg, South Africa
C H R O N I C L E

Article history:

Received: June 12, 2021

Received in revised format:

July 22021

Accepted: August 10, 2021

Available online:

August 11, 2021

Keywords:

Smallholder horticulture store

Perceived service quality

Product quality

Price

Corporate social responsibility

Satisfaction

Word of mouth

\section{A B S T R A C T}

Based on the expectancy disconfirmation theory, the study presents a conceptual model exploring consumer perception (perceived service quality, product quality, price, and corporate social responsibility) effect on satisfaction and word of mouth in smallholder horticulture stores. A quantitative analysis using Partial Least Squares-based Structural Equation Modeling (PLS-SEM) was carried. This method was used to identify elements influencing satisfaction and to explore the hypothesised relationships between consumer perceptions, satisfaction, and the spreading of positive word of mouth. The findings identify the perceived service quality and product quality as factors that enhance satisfaction. However, the perceived quality of the product is the only factor that aids word of mouth. Correspondingly, perceived product quality shows a favorable relationship with perceived price. On the other hand, perceived price and corporate social responsibility do not strengthen customer satisfaction, with corporate social responsibility not aiding word of mouth. Furthermore, the study tested the strength of customer satisfaction as a mediating variable between consumer perception and word of mouth, and none of the results proved significant. Similarly, perceived price does not mediate the path between perceived product quality and customer satisfaction. The study is of benefit to scholars, smallholders, and agricultural policymakers, particularly in emerging economies.
\end{abstract}

\section{Introduction}

As one of the most significant sectors of the economy, the agricultural industry is considered a priority internationally as products produced are a necessity for human existence and survival (Beckman \& Countryman, 2021). The agricultural sector can assist in improving food security and reducing poverty (The World Bank, 2020). According to The World Bank (2020), the sector contributed about (4\%) to the global gross domestic product (GDP), and about (25\%) contribution to the GDP was from some of the emerging economies. However, economies have been experiencing the impact of climate change throughout the world. Some of these changes are more visible than others, such as the decline of soil fertility and scarcity of water which has negatively affected agriculture production (Williams et al., 2019). The World Economic Forum (2019) highlighted the use of agriculture to fight climate change using carbon. Carbon can be converted to soil organic matter and plant material, which can improve the health of the soil and, in turn, increase the aptitude of production on the land (World Economic Forum (2019). Agro-ecological methods and organic agriculture are essential for developing agricultural policy agendas, especially in sub-Saharan Africa (Adenle et al., 2019). Therefore to preserve ecological balance, food security, and the production of raw materials, the focus on horticulture crops becomes vital, as recommended by authors (Malik \& Azhar, 2018). Horticulture is a subdivision of agriculture and focuses on gardening plants, fruits, and vegetables (Isaak \& Lentz, 2020). Moreover, from a health and lifestyle perspective, horticulture plays a role in stimulating the positive well-being of people through nurturing spaces that are important to people, such as home gardening, community parks, sports fields, and botanical gardens (Meyer et al., 2016). Being a rapidly developing industry in the agricultural sector (Elansary et al., 2017), this study seeks to draw its * Corresponding author.

E-mail address: melissa.zulu@wits.ac.za (V. M. Zulu)

(C) 2022 by the authors; licensee Growing Science, Canada doi: $10.5267 / \mathrm{j} . \mathrm{msl} .2021 .8 .004$ 
attention to horticulture within an emerging economy in Sub-Saharan Africa. More importantly, prioritising the smallholder in South Africa. The agricultural industry in South Africa is dominated by commercial farms and smallholders, although the smallholder occupies a small percentage of the farming land (Tibesigwa et al., 2017). Smallholder farmers have difficulty compared to commercial farmers, especially when it comes to barriers to profitability which highlight the lack of market access (Fan \& Rue, 2020). However, even with the small occupancy of land, and lack of market access, the smallholding creates jobs and provides the economic livelihood for communities. For example, horticulture in the Tanzanian economy is the fastest-growing subsector, providing food security and employment opportunities for communities, particularly women (Mrema et al., 2017). Thus, this demonstrates that the role of the smallholder has grown over time, yet, there is little academic research that can be found on smallholder horticultural products or store customer perception, particularly in emerging economies.

There has been a lot of studies done in emerging economies (Elansary et al., 2017; Mrema et al., 2017; Pasquali et al., 2021; Sun et al., 2019; Tibesigwa et al., 2017; Van Kleunen et al., 2018; Williams et al., 2019) highlighting the importance of horticulture. Many of the studies, if not all, focus on the farmer (producing) perspective and little focus from the consumers' point of view. In South Africa, the agriculture, forestry, and fisheries department introduced the Smallholder Horticulture Empowerment and Promotion (SHEP) project, encouraging small business farmers to grow to sell their produce (Department of Agriculture, 2019). However, for a business to thrive, its customers are its backbone. Therefore, serving consumers well, both from a product and service point of view, increases satisfaction. In turn, consumers become advocates, encouraging word of mouth, which is very important for small businesses that rely on their consumers to spread the word. A Thailand study (Prasertsaeng et al., 2020) investigated elements that impact farmers satisfaction within horticultural companies' activities. However, the study was conducted from the production perspective. There is limited evidence on the influence of customer perception on horticultural products or services, particularly in Sub-Saharan Africa within small businesses. This study aims to identify and inspect elements that affect customer satisfaction and word of mouth of a smallholder horticultural store. The research objectives are as follows:

a) To identify factors that lead to customer satisfaction of a smallholder horticultural store;

b) To explore the relationship between the perceptions of service quality, product quality, price, corporate social responsibility, and customer satisfaction of a smallholder horticultural store;

c) To investigate the influence customer satisfaction has on word of mouth of a smallholder horticultural store;

d) To test the mediating role of satisfaction between the perceived service quality, product quality, price, corporate social reasonability, and word of mouth of a smallholder horticultural store; and

e) To assess the mediating role of perceived price amongst perceived product quality and satisfaction.

\section{Literature review}

\subsection{Expectancy disconfirmation theory}

The Expectancy Disconfirmation Paradigm (EDP) by Oliver (1980), cited in (Hossain, 2019) describes the role of the customer's prior expectations using a cognitive process where satisfaction judgments have been formed through experiences or expectations (Morgeson, 2012). The EDP is the most widely used marketing literature model for customer (dis)satisfaction (Hossain, 2019). However, limited studies have applied the theory to smallholder horticultural products and stores. As such, the study will use the approach to ground the research. EDP recognises shopper behaviour in three phases as stated by (Guo et al., 2015): (1) purchase stage, (2) confirmation/disconfirmation stage, and (3) the response/feedback stage. In the purchase phase, shoppers develop initial anticipation of the product or service. To determine the role of expectation, the study assesses perceived service quality, product quality, price, and corporate social responsibility. For the confirmation/disconfirmation stage, this study will measure customer satisfaction and positive word of mouth for the response/feedback stage. EDP is relevant to this study because it relates to customers' perceptions of the quality of the service, product, price, and corporate social responsibility of the smallholding horticultural store. Consumers have pre-purchase and post-use expectations of the services and products they consume; depending on the outcome of these expectations, whether satisfied or not, confirmation or disconfirmation occurs (Oliveri et al., 2019).

\subsection{Perceived service quality}

Severi and Ling (2013) define the perceived quality of services as consumers' perception of the excellence and quality of services. These include a shopper's anticipation of how a store will deliver the service. Depending on the outcome of the expectation, the quality of the service can positively affect purchasing decisions (Su et al., 2016). Scholars argue that understanding a customer's expectation can allow a business to provide high-quality service fundamentals and be successful (Brochado \& Pereira, 2017). Therefore, to compete successfully, service quality is one of the key features to be considered when companies map out their customer journeys (Martins et al., 2015), which justifies the inclusion of this construct for the current study. Since services are intangible and based on individual personal experiences, to evaluate the perceived service 
quality of the smallholder's horticultural store, this study will focus on whether customers receive particular attention, promptness of the service, and the effectiveness of customer complaint feedback. Examining the service quality perceptions for improving performance, satisfaction, and retention is vital for brands (Orel \& Kara, 2014). Consequently, since customers determine the quality of service, firms should aim to execute the features and characteristics expected of that service (De Oña et al., 2013). Perceived service quality has been proven to have a positive relationship with positive word-of-mouth (Ahmadi, 2019; Casidy, 2014; Liu \& Lee, 2016) and customer satisfaction (Ahmadi, 2019; Boonlertvanich, 2019; Jeaheng et al., 2020; Murti et al., 2013; Pooya et al., 2020). Based on the discussed literature, it is proposed that:

$\mathrm{H}_{1}$ : Perceived service quality will stimulate positive word of mouth.

$\mathrm{H}_{2}$ : Perceived service quality will enhance customer satisfaction.

\subsection{Perceived product quality}

Perceived product quality could anticipate a consumer's identification with a store (Nikhashemi et al., 2017). Consumer perceptions of product quality are determined by products' overall superiority and supremacy (Jhandir, 2012; Razak et al., 2016). Perceived product quality is considered influential for consumers and highly related to purchasing decisions (Ariffin et al., 2016). The perceptions customers have about the quality of the product are also influenced by the customer's ethnocentrism (Purwanto, 2014). This study justifies perceived product quality as an essential construct to explore since the smallholding horticultural store produces local products. Ultimately, perceived product quality determines whether customer's expectations of the product have been achieved (Quattelbaum et al., 2013). Razak et al. (2016) state that consumers perceive products to be of good quality if they are associated with their expectations, leading to their satisfaction. Positive perception of a product's quality has been shown to affect customer satisfaction (Nikhashemi et al., 2017). Studies (Jeong \& Jang, 2011; Konuk, 2019) have found that perceived food quality positively affects satisfaction and word of mouth (Mukerjee, 2018). Moreover, in a study about halal, scholars (Jeaheng et al., 2020) proposed that halal foods and services influence customer satisfaction and perceived price. Therefore, it is suggested that:

$\mathrm{H}_{3}$ : Perceived product quality will stimulate positive word of mouth.

$\mathrm{H}_{4}$ : Perceived product quality will enhance customer satisfaction.

$\mathrm{H}_{5}$ : Perceived product quality will have a positive effect on the perceived price.

\subsection{Perceived Price}

Perceived price is the price customers determine for the value and benefits derived from products and services customers consume and plays a vital role in customer purchase decision making (Jeaheng et al., 2020; Kaura et al., 2014; Yoon et al., 2014). Perceived price is a vital determinant in consumer buying and significantly influences consumers' judgment regarding the product and service (Kaura et al., 2015). To measure perceived price, this study will use affordability, suitability, and fairness. Perceived price fairness is essential for a smallholder horticultural store as it services local communities that are price sensitive. Perceived price fairness is the shopper's evaluation of whether the price is reasonable, acceptable, and justifiable (Kaura et al., 2014). Perceived price varies across customers (Beneke \& Zimmerman, 2014) and has been found to affect customer satisfaction (Kaura et al., 2014; Konuk, 2019). It is therefore proposed that:

$\mathrm{H}_{6}$ : Perceived price will enhance customer satisfaction; and that

$\mathrm{H}_{11}$ : Perceived price will mediate the oath amongst perceived product quality and satisfaction.

\subsection{Corporate Social Responsibility (CSR)}

Corporate Social Responsibility (CSR) is beyond making profits in a company. It aims to contribute to the social good in the community, and it goes beyond the interest of the company (Salib et al., 2015). CSR is when a company voluntarily contributes to improve society and encourage a better and cleaner environment (Setó-Pamies \& \& Papaoikonomou, 2016). According to Salib et al. (2015), There are two types of CSR: traditional and contemporary. In traditional CSR, a company gives back without any societal considerations, and contemporary CSR is when social responsibility is incorporated into the company's functioning. The latter is the adopted definition for this study, which is also important within the agricultural sector, making it importan to the smallholder horticultal producer esepcially given issues pertaining to climate change which affect communities. CSR assists companies in enhancing their brand image and positive customer perceptions, which is influential for product and service differentiation (Lee et al., 2020). Therefore CSR demonstrates the responsibilities businesses should take to contribute to bettering society and protect the environment. This study will focus on environmental friendliness, product health, and good working conditions to measure CSR. Prior research has shown that customers favour companies involved with CSR, which influences positive customer behaviours (Rita et al., 2019). As such, companies committed to corporate social responsibility have been found to enhance customer satisfaction (Park et al., 2017) and favourable word of mouth (Hanaysha, 2021; Vo et al., 2019). The study, therefore, proposes the following relationships:

$\mathrm{H}_{7}$ : Corporate social responsibility will enhance customer satisfaction. 
$\mathrm{H}_{8}$ : Corporate social responsibility will stimulate positive word of mouth.

\subsection{Customer Satisfaction and Word of Mouth}

Customer satisfaction is fundamental in marketing practice and can determine whether a company succeeds or fails. Hence the ultimate objective for organisations is to satisfy their customers (Rita et al., 2019). Satisfaction has been linked with the performance of businesses (Eklof et al., 2020), market share (Rego et al., 2013), and a positive contributor to word of mouth (WOM) (Eisingerich et al., 2014; Rego et al., 2013; Rita et al., 2019). These relationships demonstrate the importance of ensuring that customers are satisfied, especially for smallholder horticultural stores operating at smaller scales relying on word of mouth to reach out to more consumers. Consumers often share their interpersonal experiences and information, whether positive or negative, about products with one another and this aids in spreading awareness about a brand and at no cost to the company. For a horticultural smallholder, this is important because consumers of the stores will market the products and services on their behalf, which is vital for local stores servicing communities face to face. Word of mouth (WOM) is a critical marketing tool that can impact consumer preferences and choices (Hanaysha, 2021). Customer satisfaction has been found to affect word of mouth (Pfeffer et al., 2014). Eisingerich et al. (2015) posit that there are two types of WOM: online WOM and offline WOM. Online WOM is when the consumer expresses their opinion or experience of a particular item on the Internet or social media platforms, whereas offline involves face-to-face communication (Eisingerich et al., 2014). For this study, the latter applies. Although there are many positive benefits of word of mouth, there are also some negative aspects (Pfeffer et al., 2014). These become evident when consumers are not happy with a product or service, which can be fatal for brands. This justifies why a smallholder store should thrive on satisfying customers because it relies on them to communicate positively about their stores. For this study, word of mouth being referred to is positive. It is therefore proposed that:

$\mathrm{H}_{9}$ : Customer satisfaction will stimulate positive word of mouth.

$\mathrm{H}_{10}$ : Customer satisfaction will mediate the path amongst customer perceptions and word of mouth.

For the outline of the proposed conceptual model, see Fig.1.

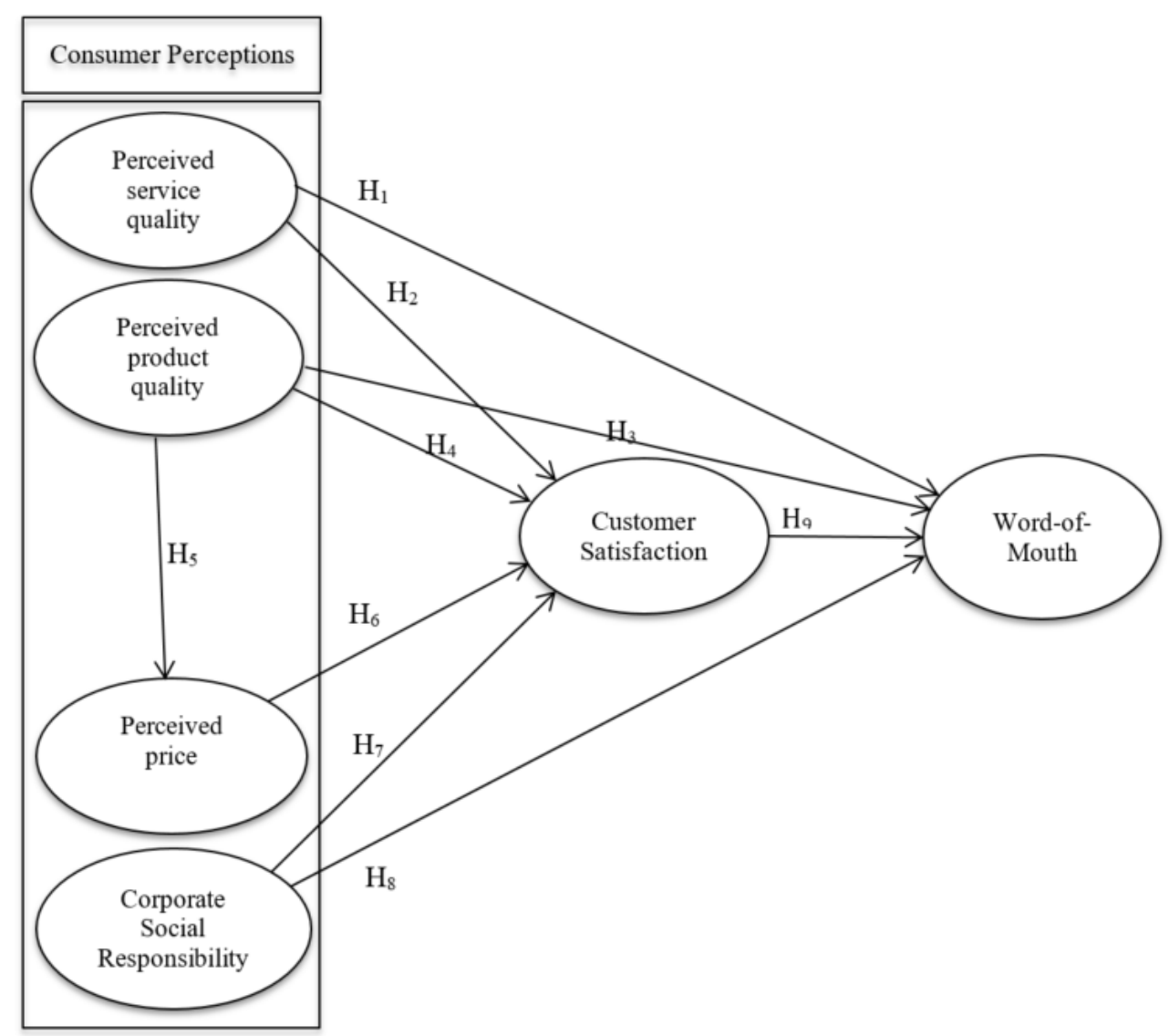

Fig. 1. The proposed conceptual model 


\section{Research methods}

The study adopted quantitative methods, and a questionnaire (self-administered) was used for data collection. The proposed conceptual model consisted of perceived service quality measured using four items adapted from (Severi \& Ling, 2013), while perceived product quality consisted of six measurement items adapted from (Washburn \& Plank, 2002). Perceived price used four measurement items adapted from (Chiang \& Jang, 2007), and corporate social responsibility included four measurement items adapted from (Anselmsson \& Johansson, 2007). Customer satisfaction had four measurement items adapted from (Martin et al., 2015). Meanwhile, word of mouth was measured using seven items adapted from (Brown et al., 2005). The items were measured using a five-point Likert scale, from 1 "strongly disagree" to 5 "strongly agree." All items are indicated in Fig. 2 and appendices.

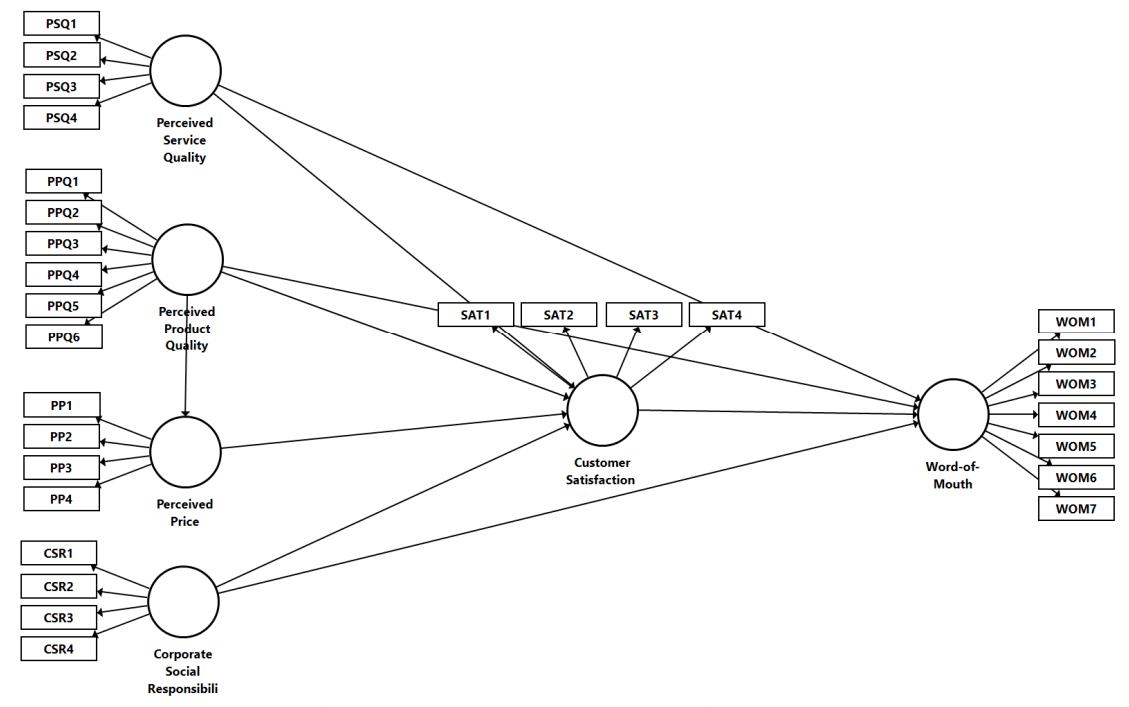

Fig. 1. The conceptual model depicted on SmartPLS

The questionnaire consisted of two sections; section A was the demographic profile of respondents, and section B was for measurement items. Statistical Package for the Social Sciences (SPSS) was used to analyse data for section A. For section B, partial least squares-based structural equation modeling (PLS-SEM) was used for path analysis conducted in SmartPLS 3. PLS-SEM is selected since the study aims to identify, explore and examine factors that affect customers' satisfaction and, in turn, positive word of mouth of a smallholder horticultural store. This is also justified by Hair et al. (2011), who states that if a study aims to identify or explore constructs as key drivers, then PLS-SEM is recommended.

Smallholder horticulture producers typically service their local communities, but market access is still a challenge, especially from a business-to-business environment. Hence some smallholders have also opened their stores to sell directly to customers, which is not an extensive customer base. Taking this into consideration and that there was no sampling frame to draw from, the study made use of a non-probability convenience sampling technique. This method was selected for ease of access to participants and their readiness to participate (Farrokhi \& Mahmoudi-Hamidabad, 2012), which was essential to obtain an ethical clearance certificate. Moreover, convenience sampling enabled the study to reach particular customers with underlying knowledge and experience (Tucker et al., 2015) on consuming horticultural products and services from smallholders' stores. Customers who are knowledgeable and experienced on the subject matter will provide meaningful feedback to enable the study to answer the research questions (Tucker et al., 2015).

From a sample size perspective, PLS-SEM can work with an extensive range of sample sizes competently. One of the advantages of using PLS-SEM is that it allows a smaller sample size (Kock \& Hadaya, 2018). This also deems the sample size used for the study adequate. It is also recommended that should a sample size be small $(\mathrm{n}<100)$, PLS-SEM must be selected (Hair et al., 2017). However, Hair et al. (2011) the sample size should be "ten times the largest number of structural paths directed at a particular latent construct in the structural model" (pp.144). The study meets the condition. Furthermore, authors (Lin et al., 2020) also found that small sample sizes, predictive models, and non-normal data were amongst the three common reasons studies used PLS-SEM.

With the smallholding stores having a smaller customer database than commercial farmers, obtaining a larger sample size can prove challenging as the population size (total number of smallholder horticultural customers) is unclear. Therefore, the study targeted a sample size of 100 . Ninety-five (95) responses were successfully collected, making it a response rate of $95 \%$. It should be pointed out that before data collection, a pilot study was conducted to ascertain the reliability and validity of the constructs and respective measurement items. The pilot test was necessary, seeing that limited studies of this nature have been 
conducted in this context. The pilot test consisted of 20 respondents, which is more than sufficient given that the suggested sample size for a pilot study should be $10-20 \%$ of the primary sample size (Hazzi \& Maldaon, 2015).

\section{Results}

\subsection{Demographic profile of respondents}

Section A of the questionnaire included collecting information on the demographic profile and characteristics. These included gender, marital status, age, highest academic qualification, and occupation. This is a summary, however for a complete breakdown, please see Table 1 . The majority of the respondents were females $(60 \%)$, and males were $(40 \%)$. The majority of the participants were married (63.15\%). The majority age group was $26-35$ years of age $(29.47 \%)$, followed by $36-45$ years of age $(25.26 \%)$, after that, $56-75$ years of age $(21.05 \%)$. The majority of the participants had university postgraduate degrees (40\%), followed by $26.31 \%$ of participants with degrees, $15.79 \%$ of the participants had diplomas, $14.74 \%$ had high school education. Approximately $50.53 \%$ of the participants were employed, $26.32 \%$ were self-employed, and $10.53 \%$ were students.

Table 1

Profile of respondents

\begin{tabular}{|c|c|c|c|c|c|}
\hline Category & Characteristic & Percentage (\%) & & & \\
\hline \multirow[t]{2}{*}{ Gender } & Female & 60 & \multirow[t]{5}{*}{ Qualification } & High school & 15 \\
\hline & Male & 40 & & Diploma & 16 \\
\hline \multirow[t]{4}{*}{ Marital Status } & Married & 63 & & Degree & 26 \\
\hline & Single & 29 & & Postgraduate de- & 40 \\
\hline & Divorced & 6 & & Other & 3 \\
\hline & Prefer not to say & 2 & \multirow[t]{6}{*}{ Occupation } & Student & 11 \\
\hline \multirow[t]{5}{*}{ Age } & $18-25$ years & 9 & & Employed & 51 \\
\hline & $26-35$ years & 29 & & Self-employed & 26 \\
\hline & $36-45$ years & 25 & & Unemployed & 3 \\
\hline & $46-55$ years & 15 & & Other & 9 \\
\hline & $56-75$ years or older & 21 & & & \\
\hline
\end{tabular}

\subsection{Assessment of the reflective measurement model}

Examining the measurement model is the first step in assessing PLS-SEM results as recommended by (Hair et al., 2019). This includes evaluating the measurement model, which contains estimating indicator loadings $(>0.700)$ (Hair et al., 2017) for testing satisfactory reliability of the measurement items. Loadings below 0.700 were deleted, which led to an increase in the composite reliability.

Table 2

$\underline{\text { Reflective measurement model analysis }}$

\begin{tabular}{|c|c|c|c|c|c|c|}
\hline Constructs & & Indicator Loadings & $\begin{array}{c}\text { Cronbach's } \\
\text { Alpha }\end{array}$ & $\begin{array}{c}\text { Composite Reliability } \\
\text { (CR) }\end{array}$ & $\begin{array}{c}\text { Average } \\
\text { Variance Ex- } \\
\text { tracted (AVE) }\end{array}$ & $\begin{array}{c}\text { Variance Infla- } \\
\text { tion Factor (VIF) }\end{array}$ \\
\hline Perceived Service & PSQ1 & 0.812 & \multirow[t]{3}{*}{0.788} & \multirow[t]{3}{*}{0.876} & \multirow[t]{3}{*}{0.703} & 1.553 \\
\hline \multirow[t]{2}{*}{ Quality (PSQ) } & PSQ2 & 0.852 & & & & 1.747 \\
\hline & PSQ4 & 0.851 & & & & 1.703 \\
\hline Perceived Product & PPQ1 & 0.816 & \multirow[t]{5}{*}{0.908} & \multirow[t]{5}{*}{0.932} & \multirow[t]{5}{*}{0.732} & 2.121 \\
\hline \multirow[t]{4}{*}{ Quality (PPQ) } & PPQ2 & 0.879 & & & & 3.483 \\
\hline & PPQ3 & 0.892 & & & & 3.797 \\
\hline & PPQ4 & 0.865 & & & & 2.753 \\
\hline & PPQ5 & 0.825 & & & & 2.304 \\
\hline \multirow[t]{3}{*}{ Perceived Price (PP) } & PP2 & 0.919 & \multirow[t]{3}{*}{0.904} & \multirow[t]{3}{*}{0.940} & \multirow[t]{3}{*}{0.839} & 3.261 \\
\hline & PP3 & 0.937 & & & & 3.427 \\
\hline & PP4 & 0.892 & & & & 2.456 \\
\hline Corporate Social & CSR1 & 0.835 & \multirow[t]{4}{*}{0.810} & \multirow[t]{4}{*}{0.875} & \multirow[t]{4}{*}{0.636} & 2.075 \\
\hline \multirow[t]{3}{*}{ Responsibility (CSR) } & CSR2 & 0.814 & & & & 1.599 \\
\hline & CSR3 & 0.729 & & & & 1.457 \\
\hline & CSR4 & 0.808 & & & & 1.852 \\
\hline \multirow{4}{*}{$\begin{array}{l}\text { Customer Satisfaction } \\
\text { (SAT) }\end{array}$} & SAT1 & 0.760 & \multirow{4}{*}{0.856} & \multirow[t]{4}{*}{0.903} & \multirow[t]{4}{*}{0.699} & 1.776 \\
\hline & SAT2 & 0.873 & & & & 2.816 \\
\hline & SAT3 & 0.875 & & & & 2.735 \\
\hline & SAT4 & 0.832 & & & & 1.991 \\
\hline \multirow[t]{6}{*}{ Word of Mouth (WOM) } & WOM1 & 0.700 & \multirow[t]{6}{*}{0.917} & \multirow[t]{6}{*}{0.936} & \multirow[t]{6}{*}{0.710} & 1.684 \\
\hline & WOM3 & 0.890 & & & & 3.154 \\
\hline & WOM4 & 0.884 & & & & 3.594 \\
\hline & WOM5 & 0.829 & & & & 2.481 \\
\hline & WOM6 & 0.839 & & & & 2.684 \\
\hline & WOM7 & 0.898 & & & & 4.049 \\
\hline
\end{tabular}


This consideration is supported by (Hair et al., 2011). The second phase is the composite reliability (CR) for internal consistency assessment, which should be above the values of 0.60 . However, less than 0.95 (Hair et al., 2019), the internal consistency test also includes the Cronbach's alpha ( $>0.70)$ (Ibrahim \& Aljarah, 2018; Taber, 2018). The third phase of the reflective measurement model evaluation includes assessing the convergent validity of constructs, which is tested using the average variance extracted (AVE), which should be $(>0.50)$. The study met all the conditions of these tests, as shown in Table 1 , depicting that internal consistency and construct validity (variance of items per construct) are evident.

The fourth phase of the reflective measurement model evaluation assesses the discriminant validity. For this assessment, Fornell and Larcker (1981), as cited in (Hair et al., 2019), was analysed. To confirm discriminant validity using Fornell and Larcker (1981) method, the AVE of each construct should be greater than the shared variance for all constructs in the conceptual model, which is achieved as shown in Table 2. However, the Heterotrait-Monotrait (HTMT) ratio has been suggested as a new method to determine discriminant validity (Henseler et al., 2015). Voorhees et al. (2016) maintained that the drive for this new test for discriminant validity is related to the need to create the content and solidness of constructs and is necessary for researchers to demonstrate that all constructs are distinct. For discriminant validity to not be violated, the HTMT ratio should be below 0.85 , preferably below 0.90 (Henseler et al., 2015). As demonstrated in Table 2, the HTMT values are within the recommended threshold, signalling that discriminant validity is present.

Table 3

Fornell and Larcker (1981) and Heterotrait-monotrait (HTMT) ratio

\begin{tabular}{|c|c|c|c|c|c|c|}
\hline & & & d Larc & & & \\
\hline & CSR & SAT & PP & PPQ & PSQ & WOM \\
\hline CSR & 0.798 & & & & & \\
\hline SAT & 0.290 & 0.836 & & & & \\
\hline PP & 0.078 & 0.249 & 0.916 & & & \\
\hline PPQ & 0.307 & 0.653 & 0.226 & 0.856 & & \\
\hline PSQ & 0.286 & 0.774 & 0.377 & 0.694 & 0.838 & \\
\hline WOM & 0.262 & 0.491 & 0.159 & 0.516 & 0.539 & 0.843 \\
\hline & & & notrait & & & \\
\hline & CSR & SAT & PP & PPQ & PSQ & WOM \\
\hline CSR & & & & & & \\
\hline SAT & 0.336 & & & & & \\
\hline PP & 0.201 & 0.280 & & & & \\
\hline PPQ & 0.357 & 0.732 & 0.245 & & & \\
\hline PSQ & 0.316 & 0.877 & 0.406 & 0.773 & & \\
\hline WOM & 0.277 & 0.535 & 0.179 & 0.538 & 0.620 & \\
\hline
\end{tabular}

Table 4 demonstrates the cross-loadings, which meet the criteria for evident discriminant validity (Khan, 2021).

Table 4

Cross-loadings

\begin{tabular}{|c|c|c|c|c|c|c|}
\hline & CSR & PP & PPQ & PSQ & SAT & WOM \\
\hline CSR1 & 0.835 & 0.089 & 0.264 & 0.254 & 0.257 & 0.134 \\
\hline CSR2 & 0.814 & -0.122 & 0.213 & 0.206 & 0.265 & 0.260 \\
\hline CSR3 & 0.729 & 0.192 & 0.189 & 0.225 & 0.203 & 0.164 \\
\hline CSR4 & 0.808 & 0.149 & 0.312 & 0.235 & 0.191 & 0.254 \\
\hline PP2 & 0.095 & 0.919 & 0.221 & 0.333 & 0.182 & 0.114 \\
\hline PP3 & 0.092 & 0.937 & 0.223 & 0.363 & 0.260 & 0.182 \\
\hline PP4 & 0.025 & 0.892 & 0.175 & 0.338 & 0.235 & 0.135 \\
\hline PPQ1 & 0.195 & 0.172 & 0.816 & 0.555 & 0.543 & 0.400 \\
\hline PPQ2 & 0.250 & 0.205 & 0.879 & 0.577 & 0.520 & 0.406 \\
\hline PPQ3 & 0.262 & 0.280 & 0.892 & 0.655 & 0.545 & 0.527 \\
\hline PPQ4 & 0.274 & 0.202 & 0.865 & 0.641 & 0.583 & 0.480 \\
\hline PPQ5 & 0.328 & 0.095 & 0.825 & 0.532 & 0.605 & 0.381 \\
\hline PSQ1 & 0.169 & 0.255 & 0.531 & 0.812 & 0.647 & 0.384 \\
\hline PSQ3 & 0.275 & 0.298 & 0.623 & 0.852 & 0.636 & 0.482 \\
\hline PSQ4 & 0.271 & 0.389 & 0.590 & 0.851 & 0.663 & 0.485 \\
\hline SAT1 & 0.187 & 0.200 & 0.439 & 0.534 & 0.760 & 0.346 \\
\hline SAT2 & 0.195 & 0.181 & 0.529 & 0.626 & 0.873 & 0.389 \\
\hline SAT3 & 0.350 & 0.213 & 0.651 & 0.722 & 0.875 & 0.497 \\
\hline SAT4 & 0.210 & 0.237 & 0.538 & 0.682 & 0.832 & 0.390 \\
\hline WOM1 & 0.200 & 0.160 & 0.214 & 0.387 & 0.390 & 0.700 \\
\hline WOM3 & 0.315 & 0.171 & 0.545 & 0.516 & 0.479 & 0.890 \\
\hline WOM4 & 0.247 & 0.049 & 0.458 & 0.474 & 0.405 & 0.884 \\
\hline WOM5 & 0.092 & 0.078 & 0.426 & 0.423 & 0.416 & 0.829 \\
\hline WOM6 & 0.176 & 0.135 & 0.424 & 0.425 & 0.340 & 0.839 \\
\hline WOM7 & 0.262 & 0.210 & 0.477 & 0.482 & 0.442 & 0.898 \\
\hline
\end{tabular}




\subsection{Assessment of the structural models}

The assessment of the measurement model is acceptable, and therefore the next stage is assessing the PLS-SEM results of the structural model. However, before proceeding with the analysis, it is crucial to check multicollinearity. To check multicollinearity, the Variance Inflation Factor (VIF) values will be assessed. All the values for VIF were below 5 (ranged between 1.457 - 4.049) as outlined in Table 2, which are satisfactory and indicating that there are no issues of collinearity (Ali \& Park, 2016; Khan, 2021). The $\mathrm{R}^{2}$ assessment showed the following values: customer satisfaction (0.628) demonstrating a moderate effect, word of mouth (0.340) indicating a medium, and perceived price (0.021) depicting a low impact (Hair et al., 2019). $Q^{2}$ evaluation showed the following values: customer satisfaction (0.415) showing a moderate predictive accuracy, word of mouth (0.229) demonstrating a medium predictive accuracy, and perceived price (0.036) showing a small predictive accuracy (Hair et al., 2019). These values are also larger than 0 (Hair et al., 2011). The Standardised Root Mean Square Residual (SRMR) was also acceptable at 0.069 (saturated model) and 0.078 (estimated model), which is below the recommended threshold of $(<0.080)$ (David et al., 2020).

To assess the significance of the hypothesized relationships, bootstrapping was used with a minimum sample of 5000 (Hair et al., 2011). Table 7 shows that $\mathrm{H} 2(\beta=0.629, \mathrm{t}=6.465, \mathrm{p}<0.000), \mathrm{H} 3(\beta=0.273, \mathrm{t}=1.609, \mathrm{p}<0.05), \mathrm{H} 4(\beta=0.211, \mathrm{t}=$ 2.072, $\mathrm{p}<0.05)$, and H5 $(\beta=0.226, \mathrm{t}=2.163, \mathrm{p}<0.05)$ were supported and significant. Contrarily, $\mathrm{H} 1(\beta=0.273, \mathrm{t}=1.609$, $\mathrm{ns})$, H6 ( $\beta=-0.040, \mathrm{t}=0.570, \mathrm{~ns}), \mathrm{H} 7(\beta=0.048, \mathrm{t}=0.492, \mathrm{~ns}), \mathrm{H} 8(\beta=0.082, \mathrm{t}=0.826$, ns $)$, and H9 $(\beta=0.102, \mathrm{t}=0.573$, ns) were not significant. Therefore, not supported.

\section{Table 5}

Assessment of the structural model

\begin{tabular}{|c|c|c|c|c|c|}
\hline Hypotheses & Path & Path Coefficient $(\beta)$ & t-values & P Values & Decision \\
\hline H1 & $\mathrm{PSQ} \rightarrow \mathrm{WOM}$ & 0.273 & 1.609 & $0.108^{\text {ns }}$ & Not supported \\
\hline H2 & $\mathrm{PSQ} \rightarrow \mathrm{SAT}$ & 0.629 & 6.465 & $0.000 * * *$ & Supported \\
\hline H3 & $\mathrm{PPQ} \rightarrow \mathrm{WOM}$ & 0.273 & 1.609 & $0.024^{*}$ & Supported \\
\hline H4 & $\mathrm{PPQ} \rightarrow \mathrm{SAT}$ & 0.211 & 2.072 & $0.038^{*}$ & Supported \\
\hline H5 & $\mathrm{PPQ} \rightarrow \mathrm{PP}$ & 0.226 & 2.163 & $0.031 *$ & Supported \\
\hline H6 & $\mathrm{PP} \rightarrow \mathrm{SAT}$ & -0.040 & 0.570 & $0.569^{\mathrm{ns}}$ & Not supported \\
\hline H7 & $\mathrm{CSR} \rightarrow \mathrm{SAT}$ & 0.048 & 0.492 & $0.623^{\mathrm{ns}}$ & Not supported \\
\hline H8 & $\mathrm{CSR} \rightarrow \mathrm{WOM}$ & 0.082 & 0.826 & $0.409^{\text {ns }}$ & Not supported \\
\hline H9 & $\mathrm{SAT} \rightarrow \mathrm{WOM}$ & 0.102 & 0.573 & $0.567^{\text {ns }}$ & Not supported \\
\hline
\end{tabular}

\section{The mediating role of perceived price and customer satisfaction}

The mediation (indirect effects) was also assessed using the bootstrapping method with minimum 5000 samples. Customer satisfaction does not mediate the path amongst perceived service quality, product quality, price, corporate social reasonability, and word of mouth. The results are as follows: $\mathrm{H} 10(\beta=0.064, \mathrm{t}=0.573$, ns; $\beta=0.021, \mathrm{t}=0.797, \mathrm{~ns} ; \beta=-0.004 \mathrm{t}=0.266$, $\mathrm{ns} ; \beta=0.005 \mathrm{t}=0.217$, ns). This means that this mediation is not supported. Additionally, $\mathrm{H} 11(\beta=-0.009 \mathrm{t}=0.492$, ns) was also not significant. Therefore, confirming the mediating influence of perceived price on perceived product quality and customer satisfaction is not supported.

\section{Discussion and conclusions}

\subsection{Discussion}

The study intended to identify and inspect factors that affect customer satisfaction and positive word of mouth of smallholder horticultural stores. Using the Expectancy Disconfirmation Paradigm (EDP) as a theoretical lens, the study found that in the initial purchase, product quality and service quality are the strongest factors influencing the confirmation stage (satisfaction) and, in turn, response/feedback stage (word of mouth). These findings are consistent with prior studies (Ahmadi, 2019; Jeaheng et al., 2020; Mukerjee, 2018; Pooya et al., 2020; Razak et al., 2016). These findings contribute to two scholarly fields, agriculture and marketing, by attempting to propose a model for the successful development and commercialisation of smallholder horticultural stores. Although the study also identified two more constructs as part of the initial purchase stage, the study found that these variables (perceived price and corporate social responsibility) are not necessary for this context. These findings contradict previous studies (Konuk, 2019; Liu \& Lee, 2016; Vo et al., 2019). It is not surprising since the context of the prior studies is not similar.

From a managerial perspective, the findings reveal that consumers' perception of service quality enhances satisfaction, suggesting that the higher the perceived service quality, the more pleasure will occur from the customer. Smallholder horticultural farmers and small business owners must pay attention to improving the quality of service throughout their business as it will enhance and increase the satisfaction of their customers. Additionally, the smallholder horticultural farmers should pay more attention to product quality. Consumers believe the quality of products to be satisfactory, which is why they would keep visiting the stores and spreading positive word of mouth. Moreover, smallholders need to note that factors such as price and 
corporate social responsibility do not matter to customers as long as customers receive high-quality products combined with high-quality service. Policymakers, as part of the development of agricultural policy agendas, can introduce marketing courses through incubators for smallholder farmers that focus on the importance of marketing strategy through customer service, product quality, and extent of word of mouth.

\subsection{Limitations and future research}

The study has some limitations. Firstly, the intention of the study was not to research to generalise to a more significant population. The study solely focused on a horticulture smallholder farmer's business as few studies of such nature are conducted in the space. The study seeks to start the conversation and discussion of this nature to encourage future research on this phenomenon. Secondly, the sample size does not fully represent the population of customers in this particular sector. Furthermore, the study was carried in South Africa, in one of the nine provinces, Gauteng, in Johannesburg. Future studies can adopt the model and replicate it in other provinces and emerging economies.

Thirdly, the study used a non-probability convenience sampling technique as there was no customer database to draw the sample size. Future studies can incorporate loyalty programs into the model as this will enable the smallholder to keep valuable records of customer information that can be used for marketing purposes. Moreover, given that perceived price and corporate social responsibility were not identified as essential factors, future studies can also incorporate a mixed method to unlock richer insights on these factors and others without limits provided by a structured questionnaire.

\section{Acknowledgements}

This study is based on the research supported wholly / partly by the University of the Witwatersrand Chancellor's Female Academic Leaders Fellowship.

\section{References}

Adenle, A. A., Wedig, K., \& Azadi, H. (2019). Sustainable agriculture and food security in Africa: The role of innovative technologies and international organizations. Technology in Society, 58, $1-17$. https://doi.org/https://doi.org/10.1016/j.techsoc.2019.05.007

Ahmadi, A. (2019). Thai Airways: key influencing factors on customers' word of mouth. International Journal of Quality \& Reliability Management, 36(1), 40-57. https://doi.org/ https://doi.org/10.1108/IJQRM-02-2018-0024

Ali, M., \& Park, K. (2016). The mediating role of an innovative culture in the relationship between absorptive capacity and technical and non-technical innovation. Journal of business research, 69(5), 1669-1675. https://doi.org/https://doi.org/10.1016/j.jbusres.2015.10.036

Anselmsson, J., \& Johansson, U. (2007). Corporate social responsibility and the positioning of grocery brands: An exploratory study of retailer and manufacturer brands at point of purchase. International Journal of Retail \& Distribution Management, 36(10), 835-856. https://doi.org/https://doi.org/10.1108/09590550710820702

Ariffin, S., Yusof, J. M., Putit, L., \& Shah, M. I. A. (2016). Factors influencing perceived quality and repurchase intention towards green products. Procedia Economics and Finance, 37, 391-396. https://doi.org/https://doi.org/10.1016/S2212$\underline{5671(16) 30142-3}$

Beckman, J., \& Countryman, A. M. (2021). The Importance of Agriculture in the Economy: Impacts from COVID-19. American journal of agricultural economics, 1-17. https://doi.org/https://doi.org/10.1111/ajae.12212

Beneke, J., \& Zimmerman, N. (2014). Beyond private label panache: the effect of store image and perceived price on brand prestige. Journal of Consumer Marketing, 31(4), 301-311. https://doi.org/https://doi.org/10.1108/JCM-12-2013-0801

Boonlertvanich, K. (2019). Service quality, satisfaction, trust, and loyalty: the moderating role of main-bank and wealth status. International Journal of Bank Marketing, 37(1), 278-302. https://doi.org/https://doi.org/10.1108/IJBM-02-2018-0021

Brochado, A., \& Pereira, C. (2017). Comfortable experiences in nature accommodation: Perceived service quality in Glamping. Journal of Outdoor Recreation and Tourism, 17, $77-83$. https://doi.org/https://doi.org/10.1016/j.jort.2017.01.005

Brown, T. J., Barry, T. E., Dacin, P. A., \& Gunst, R. F. (2005). Spreading the word: Investigating antecedents of consumers' positive word-of-mouth intentions and behaviors in a retailing context. Journal of the academy of marketing science, 33(2), 123-138. https://doi.org/https://doi.org/10.1177/0092070304268417

Casidy, R. (2014). Linking brand orientation with service quality, satisfaction, and positive word-of-mouth: Evidence from the higher education sector. Journal of Nonprofit \& Public Sector Marketing, 26(2), $142-161$. https://doi.org/https://doi.org/10.1080/10495142.2014.901004

Chiang, C. F., \& Jang, S. S. (2007). The effects of perceived price and brand image on value and purchase intention: Leisure travelers' attitudes toward online hotel booking. Journal of Hospitality \& Leisure Marketing, 15(3), 49-69. https://doi.org/https://doi.org/10.1300/J150v15n03 04

David, M. E., Carter, K., \& Alvarez, C. (2020). An assessment of attachment style measures in marketing. European Journal of Marketing, 54(12), 3015-3049. https://doi.org/ https://doi.org/10.1108/EJM-10-2018-0678 
De Oña, J., De Oña, R., Eboli, L., \& Mazzulla, G. (2013). Perceived service quality in bus transit service: a structural equation approach. Transport Policy, 29(219-226.). https://doi.org/https://doi.org/10.1016/j.tranpol.2013.07.001

Department of Agriculture, F. a. F. (2019). Smallholder horticulture empowerment and promotion approach https://www.dalrrd.gov.za/Home/aid/1129

Eisingerich, A. B., Auh, S., \& Merlo, O. (2014). Acta non verba? The role of customer participation and word of mouth in the relationship between service firms' customer satisfaction and sales performance. Journal of Service Research, 17(1), 40-53. https://doi.org/https://doi.org/10.1177/1094670513490836

Eklof, J., Podkorytova, O., \& Malova, A. (2020). Linking customer satisfaction with financial performance: an empirical study of Scandinavian banks. Total Quality Management \& Business Excellence, 31(15-16), 1684-1702. https://doi.org/https://doi.org/10.1080/14783363.2018.1504621

Elansary, O. H., Ashfaq, M., Ali, H. M., \& Yessoufou, K. (2017). The first initiative of DNA barcoding of ornamental plants from Egypt and potential applications in horticulture industry. PloS one, 12(2), 1-15. https://doi.org/https://doi.org/10.1371/journal.pone.0172170

Fan, S., \& Rue, C. (2020). The Role of Smallholder Farms in Food and Nutrition Security. In R. L. Gomez y Paloma S., Louhichi K. (Ed.), The Role of Smallholder Farms in a Changing World (pp. 13-28). Springer. https://doi.org/https://doi.org/10.1007/978-3-030-42148-9 2

Farrokhi, F., \& Mahmoudi-Hamidabad, A. (2012). Rethinking convenience sampling: Defining quality criteria. Theory \& Practice in Language Studies, 2(4), 784-792. https://doi.org/10.4304/tpls.2.4.784-792

Guo, Y., Barnes, S., \& Le-Nguyen, K. (2015). Consumer acceptance IT products: An integrative expectation-confirmation model Twenty-first Americas Conference on Information Systems, Puerto Rico.

Hair, J., Hollingsworth, C. L., Randolph, A. B., \& Chong, A. Y. L. (2017). An updated and expanded assessment of PLS$\mathrm{SEM}$ in information systems research. Industrial Management \& Data Systems, 117(3), $442-458$. https://doi.org/https://doi.org/10.1108/IMDS-04-2016-0130

Hair, J. F., Ringle, C. M., \& Sarstedt, M. (2011). PLS-SEM: Indeed a silver bullet. Journal of Marketing theory and Practice, 19(2), 139-152. https://doi.org/10.2753/MTP1069-6679190202

Hair, J. F., Risher, J. J., Sarstedt, M., \& Ringle, C. M. (2019). When to use and how to report the results of PLS-SEM. European business review, 31(1), 2-24. https://doi.org/https://doi.org/10.1108/EBR-11-2018-0203

Hanaysha, J. R. (2021). Impact of Price Promotion, Corporate Social Responsibility, and Social Media Marketing on Word of Mouth. Business Perspectives and Research, 1-16. https://doi.org/https://doi.org/10.1177/2278533721989839

Hazzi, O., \& Maldaon, I. (2015). A pilot study: Vital methodological issues. Business: Theory and Practice, 16(1), 53-62. https://doi.org/https://doi.org/10.3846/btp.2015.437

Henseler, J., Ringle, C. M., \& Sarstedt, M. (2015). A new criterion for assessing discriminant validity in variance-based structural equation modeling. Journal of the academy of marketing science, 43(1), 115-135. https://doi.org/https://doi.org/10.1007/s11747-014-0403-8

Hossain, M. J. (2019). Redefining Expectancy Disconfirmation Theory using LIS SERVQUAL+: An Integrated Framework for evaluating Library Service Quality and User Satisfaction. International Information \& Library Review, 53(3), 203216. https://doi.org/https://doi.org/10.1080/10572317.2018.1496316

Ibrahim, B., \& Aljarah, A. (2018). Dataset of relationships among social media marketing activities, brand loyalty, revisit intention. Evidence from the hospitality industry in Northern Cyprus. Data in brief, 21, 823-1828. https://doi.org/https://doi.org/10.1016/j.dib.2018.11.024

Isaak, M., \& Lentz, W. (2020). Consumer preferences for sustainability in food and non-food horticulture production. Sustainability, 12(17), 1-16. https://doi.org/https://doi.org/10.3390/su12177004

Jeaheng, Y., Al-Ansi, A., \& Han, H. (2020). Impacts of Halal-friendly services, facilities, and food and Beverages on Muslim travelers' perceptions of service quality attributes, perceived price, satisfaction, trust, and loyalty. Journal of Hospitality Marketing \& Management, 29(7), 787-811. https://doi.org/https://doi.org/10.1080/19368623.2020.1715317

Jeong, E., \& Jang, S. S. (2011). Restaurant experiences triggering positive electronic word-of-mouth (eWOM) motivations. International Journal of Hospitality $\quad$ Management, $\quad 30(2), \quad 356-366$. https://doi.org/https://doi.org/10.1016/j.ijhm.2010.08.005

Jhandir, S. U. (2012). Customer satisfaction, perceived service quality and mediating role of perceived value. International Journal of Marketing Studies, 4(1), 68-76. https://doi.org/http://dx.doi.org/10.5539/ijms.v4n1p68

Kaura, V., Prasad, C. S. D., \& Sharma, S. (2014). Impact of service quality, service convenience and perceived price fairness on customer satisfaction in Indian retail banking sector. Management and Labour Studies, 39(2), $127-139$. https://doi.org/https://doi.org/10.1177/0258042X14558188

Kaura, V., Prasad, C. S. D., \& Sharma, S. (2015). Service quality, service convenience, price and fairness, customer loyalty, and the mediating role of customer satisfaction. International journal of bank marketing 33(4), 404-422. https://doi.org/https://doi.org/10.1108/IJBM-04-2014-0048

Khan, S. M. A. (2021). Effect of Social Media Influencer Marketing on Consumers' Purchase Intention and the Mediating Role of Credibility. Journal of Promotion Management, 27(4), 503-523.

Kock, N., \& Hadaya, P. (2018). Minimum sample size estimation in PLS-SEM: The inverse square root and gammaexponential methods. Information Systems Journal, 28(1), 227-261. https://doi.org/https://doi.org/10.1111/isj.12131 
Konuk, F. A. (2019). The influence of perceived food quality, price fairness, perceived value and satisfaction on customers' revisit and word-of-mouth intentions towards organic food restaurants. Journal of Retailing and Consumer Services, 50, 103-110. https://doi.org/https://doi.org/10.1016/j.jretconser.2019.05.005

Lee, S., Han, H., Radic, A., \& Tariq, B. (2020). Corporate social responsibility (CSR) as a customer satisfaction and retention strategy in the chain restaurant sector. Journal of Hospitality and Tourism Management, 45, 348-358. https://doi.org/https://doi.org/10.1016/j.jhtm.2020.09.002

Lin, H. M., Lee, M. H., Liang, J. C., Chang, H. Y., Huang, P., \& Tsai, C. C. (2020). A review of using partial least square structural equation modeling in e-learning research. British Journal of Educational Technology, 51(4), $1354-1372$. https://doi.org/https://doi.org/10.1111/bjet.12890

Liu, C. H. S., \& Lee, T. (2016). Service quality and price perception of service: Influence on word-of-mouth and revisit intention. Journal of Air Transport $\quad$ Management, $42,54$. https://doi.org/https://doi.org/10.1016/j.jairtraman.2015.12.007

Malik, U. D., \& Azhar, M. (2018). Agriculture to Horticulture: An Innovative Method to Standardize the Socio-Economic Condition of Jammu and Kashmir. Productivity, 59(3), 236-242. https://doi.org/10.32381/PROD.2018.59.03.4

Martin, J., Mortimer, G., \& Andrews, L. (2015). Re-examining online customer experience to include purchase frequency and perceived risk. Journal of Retailing and Consumer Services, 25, 81-95. https://doi.org/https://doi.org/10.1016/j.jretconser.2015.03.008

Martins, A. L., de Carvalho, J. C., \& Ramos, T., \& Fael, J. (2015). Assessing obstetrics perceived service quality at a public hospital. Procedia-Social and Behavioral Sciences, 418 , https://doi.org/https://doi.org/10.1016/j.sbspro.2015.04.904

Meyer, M. H., Needham, D., Dole, J., Trader, B., Fox, J., Conley, M., \& Shaw, J. (2016). Importance of horticulture and perception as a career. HortTechnology, 26(2), 114-120. https://doi.org/https://doi.org/10.21273/HORTTECH.26.2.114

Morgeson, F. V. (2012). Expectations, disconfirmation, and citizen satisfaction with the US federal government: Testing and expanding the model. Journal of Public Administration Research and Theory, 23(2). https://doi.org/https://doi.org/10.1093/jopart/mus012

Mrema, E. J., Ngowi, A. V., Kishinhi, S. S., \& Mamuya, S. H. (2017). Pesticide exposure and health problems among female horticulture workers in Tanzania. Environmental health insights, , 11, 1-13. https://doi.org/https://doi.org/10.1177/1178630217715237

Mukerjee, K. (2018). The impact of brand experience, service quality and perceived value on word of mouth of retail bank customers: Investigating the mediating effect of loyalty. Journal of Financial Services Marketing, 23(1), 12-24. https://doi.org/https://doi.org/10.1057/s41264-018-0039-8

Murti, A., Deshpande, A., \& Srivastava, N. (2013). Patient satisfaction and consumer behavioural intentions: an outcome of service quality in health care services. Journal of Health Management, 15(4), 549-577. https://doi.org/https://doi.org/10.1177/0972063413516230

Nikhashemi, S. R., Valaei, N., \& Tarofder, A. K. (2017). Does brand personality and perceived product quality play a major role in mobile phone consumers' switching behaviour? Global Business Review, 18(3S), 108S-127S. https://doi.org/https://doi.org/10.1177/0972150917693155

Oliveri, A. M., Polizzi, G., \& Parroco, A. M. (2019). Measuring tourist satisfaction through a dual approach: The 4q methodology. Social Indicators Research, 146(1), 361-382. https://doi.org/https://doi.org/10.1007/s11205-018-2013-1

Orel, F. D., \& Kara, A. (2014). Supermarket self-checkout service quality, customer satisfaction, and loyalty: Empirical evidence from an emerging market. Journal of Retailing and Consumer Services, 21(2), 118-129. https://doi.org/https://doi.org/10.1016/j.jretconser.2013.07.002

Park, E., Kim, K. J., \& Kwon, S. J. (2017). Corporate social responsibility as a determinant of consumer loyalty: An examination of ethical standard, satisfaction, and trust. Journal of business research, 76, 8-13. https://doi.org/https://doi.org/10.1016/i.jbusres.2017.02.017

Pasquali, G., Krishnan, A., \& Alford, M. (2021). Multichain strategies and economic upgrading in global value chains: Evidence from Kenyan horticulture. World Development, 146, $1-21$. https://doi.org/https://doi.org/10.1016/j.worlddev.2021.105598

Pfeffer, J., Zorbach, T., \& Carley, K. M. (2014). Understanding online firestorms: Negative word-of-mouth dynamics in social media networks. Journal of Marketing Communications, $20(1-2), \quad 100-110$. https://doi.org/https://doi.org/10.1080/13527266.2013.797778

Pooya, A., Khorasani, M. A., \& Ghouzhdi, S. G. (2020). Investigating the effect of perceived quality of self-service banking on customer satisfaction. International Journal of Islamic and Middle Eastern Finance and Management, 13(2), 263-280. https://doi.org/https://doi.org/10.1108/IMEFM-12-2018-0440

Purwanto, E. (2014). The effect of consumer ethnocentrism on perceived domestic product quality and purchase intentions among young consumers in Jakarta, Indonesia. International Journal of Asian Social Science, 4(9), 1003-1012.

Quattelbaum, B., Knispel, J., Falk, B., \& Schmitt, R. (2013). Tolerancing subjective and uncertain customer requirements regarding perceived product quality. Proceedings of the Institution of Mechanical Engineers, Part B. Journal of Engineering Manufacture, 227(5), 702-708. https://doi.org/https://doi.org/10.1177/0954405412471609

Razak, I., Nirwanto, N., \& Triatmanto, B. (2016). The impact of product quality and price on customer satisfaction with the mediator of customer value. IISTE. Journal of Marketing and Consumer Research, 30, 59-68. 
Rego, L. L., Morgan, N. A., \& Fornell, C. (2013). Reexamining the market share-customer satisfaction relationship. Journal of Marketing, 77(5), 1-20. https://doi.org/https://doi.org/10.1509/jm.09.0363

Rita, P., Oliveira, T., \& Farisa, A. (2019). The impact of e-service quality and customer satisfaction on customer behavior in online shopping. Heliyon, 5(10), 1-14. https://doi.org/https://doi.org/10.1016/j.heliyon.2019.e02690

Salib, J., Sun, D., Wu, J., Wen, X., \& Huang, C. C. (2015). Corporate social responsibility. Huamin Philanthropy Brochure Series 1-22.

Setó-Pamies, D., \& \& Papaoikonomou, E. (2016). A multi-level perspective for the integration of ethics, corporate social responsibility and sustainability (ECSRS) in management education. Journal of Business Ethics, 156(3), 523-538. https://doi.org/https://doi.org/10.1007/s10551-014-2535-7

Severi, E., \& Ling, K. C. (2013). The Mediating Effects of Brand Association, Brand Loyalty, Brand Image and Perceived Quality on Brand Equity. Asian Social Science, 9(3), 125. https://doi.org/10.5539/ass.v9n3p125

$\mathrm{Su}, \mathrm{L}$., Swanson, S. R., \& Chen, X. (2016). The effects of perceived service quality on repurchase intentions and subjective well-being of Chinese tourists: The mediating role of relationship quality. Tourism management, 52, 82-95. https://doi.org/https://doi.org/10.1016/j.tourman.2015.06.012

Sun, J., Gao, H., Tian, J., Wang, J., \& Guo, S. (2019). Development status and trends of protected horticulture in China. Journal of Nanjing Agricultural University, 42(4), 594-604. https://doi.org/10.7685/jnau.201810027

Taber, K. S. (2018). The use of Cronbach's alpha when developing and reporting research instruments in science education. Research in science education, 46(8), 1273-1129. https://doi.org/https://doi.org/10.1007/s11165-016-9602-2

Tibesigwa, B., Visser, M., \& Turpie, J. (2017). Climate change and South Africa's commercial farms: an assessment of impacts on specialised horticulture, crop, livestock and mixed farming systems. Environment, Development and Sustainability, 19(2), 607-636. https://doi.org/10.1007/s10668-015-9755-6

Tucker, G. C., Windapo, A., \& Cattell, K. S. (2015). Exploring the use of financial capacity as a predictor of construction company corporate performance: evidence from South Africa. Journal of Engineering, Design and Technology, 13(4), 596-611. https://doi.org/https://doi.org/10.1108/JEDT-10-2013-0074

Van Kleunen, M., Essl, F., Pergl, J., Brundu, G., Carboni, M., Dullinger, S., \& Dehnen-Schmutz, K. (2018). The changing role of ornamental horticulture in alien plant invasions. Biological Reviews, 93(3), 1421-1437.

Vo, T. T., Xiao, X., \& Ho, S. Y. (2019). How does corporate social responsibility engagement influence word of mouth on Twitter? Evidence from the airline industry. Journal of Business Ethics, 157(2), 525-542. https://doi.org/https://doi.org/10.1007/s10551-017-3679-Z

Washburn, J. H., \& Plank, R. E. (2002). Measuring brand equity: An evaluation of a consumer-based brand equity scale. Journal of Marketing theory and Practice, 10(1), 46-62. https://doi.org/https://doi.org/10.1080/10696679.2002.11501909

Williams, P. A., Crespo, O., \& Abu, M. (2019). Adapting to changing climate through improving adaptive capacity at the local level-The case of smallholder horticultural producers in Ghana. Climate Risk Management, 23, 124-135. https://doi.org/https://doi.org/10.1016/j.crm.2018.12.004

Yoon, S., Oh, S., Song, S., Kim, K. K., \& Kim, Y. (2014). Higher quality or lower price? How value-increasing promotions affect retailer reputation via perceived value. Journal of business research, 6(10), 2088-2096. https://doi.org/https://doi.org/10.1016/j.jbusres.2014.04.017

World Economic Forum. (2019). Here's how we can use agriculture to fight climate change. https://www.weforum.org/agenda/2019/09/here-s-how-we-can-use-agriculture-to-fight-climate-change/

\section{Appendices}

Measurement instruments

Perceived service quality

- I perceive that the store provides prompt services at the promised time.

- I perceive that the store handles customer complaints effectively.

- I perceive that the store is able to tell customers exactly when the services will be performed.

- I perceive that the store gives individual customer attention.

Perceived product quality

- I perceive that the store products are of high quality.

- I perceive the quality of the store products to be extremely high.

- I perceive that the store products' functionality is very high.

- I perceive the reliability of the store products to be very high.

- I perceive that the store products must be of good quality.

- I perceive that the store products have superior quality. 
Perceived price

- My perception of the prices at the store is that they are not expensive.

- $\quad$ My perception of the prices at the store is that they are reasonable.

- My perception is that the prices at the store are appropriate.

- My perception of the prices at the store is that they are affordable.

Corporate Social Responsibility

- I perceive products of this brand to be environmentally friendly.

- I perceive products of this brand to be organic.

- I perceive the products of this brand to be healthy.

- I perceive the products of this brand to be produced under environmentally friendly conditions.

Satisfaction

- $\quad$ I am satisfied with the experience before I purchase from the store.

- I am satisfied with the purchase experience at the store.

- I am satisfied with the experience I have after I purchase from the store.

- $\quad$ I am satisfied with my overall experience at the store.

\section{Word-of-Mouth}

- I have mentioned to others that I purchase from the store.

- I make sure that others know that I purchase from the store.

- I speak positively about the store to others.

- I recommend the store to family members.

- I speak positively about the store employees to others.

- I recommend the store to acquaintances.

- I recommend the store to close personal friends. 
(C) 2022 by the authors; licensee Growing Science, Canada. This is an open access article distributed under the terms and conditions of the Creative Commons Attribution (CC-BY) license (http://creativecommons.org/licenses/by/4.0/). 